\title{
Jacek Potocki
}

\section{CHINY Z BLISKA}

Katarzyna Pawlak, Za Chiny ludowe. Zapiski z codzienności Państwa Środka, Carta Blanca PWN, Warszawa 2013, ss. 245.

Ostatnio na rynku pojawiło się wiele książek o Chinach: o ich polityce, gospodarce, bezpieczeństwie, historii - opartych na warsztacie naukowym. Są to książki niejednokrotnie dość hermetyczne, przeznaczone głównie dla ekspertów i raczej niełatwe do zgłębienia przez zwykłego czytelnika.

Bo nie jest łatwo napisać popularną, zwyczajną książkę o Państwie Środka. Ta właśnie taka jest. Przybliża polskiemu czytelnikowi Chiny codzienne, a problemy w niej ukazane często umykają uwadze turystów, naukowców, biznesmenów czy oficjeli, dość tlumnie odwiedzających Państwo Środka. Książka Katarzyny Pawlak jest czystej klasy reportażem zawierającym zapis codziennych wrażeń polskiej stażystki sinolożki z dwuletniego pobytu w Chinach w latach 2009-2011, a zwłaszcza z okresu studiów na uniwersytecie w Szanghaju i z kilku podróży po tym kraju-kontynencie, w trakcie których poznała codzienne życie zwykłych ludzi, o jakim turyści nie mają zielonego pojęcia.

Choć autorka do Chin pojechała ,przygotowana” - dość dobrze znała język i chińską kulturę - to zderzenie z realiami okazało się dla niej zaskakujące. Chiński był ,inny”, szczególnie język profesorów. Pochodzili oni z różnych rejonów kraju i posługiwali się różnymi dialektami. Katarzyna Pawlak musiała zatem pokonać stresy, wytężać uwagę, wreszcie pokonać skutecznie bariery językowe. Ale problemów, z którymi się spotykała, było znacznie więcej. Na chińskim uniwersytecie traktowano ją z przymrużeniem oka, z góry zakładano, że jest laowaj, „obca”, 
i nikt nie oczekiwał od niej wykazywania się wiedzą, mimo że przyjechała z dyplomem wyższej uczelni. Chińscy profesorowie z góry zakładają bowiem, że cudzoziemcy raczej sobie nie radzą $z$ trudnym chińskim językiem, więc i trudnych zadań im nie wyznaczają. Dlatego szefowa grupy studenckiej przydzieliła autorce byle jaki temat pracy dyplomowej, odrzucając pomysł trudniejszej rozprawki, którą ambitna Polka pragnęła napisać.

Na kartach książki znajdujemy opis życia studentów w akademikach, ich wypraw do rodzin na chińskie święta, czy wreszcie atmosfery na zajęciach. Niestety, chińscy studenci nie bardzo są zainteresowani kontaktami z „obcą”. Rzucająca się w oczy w masie ciemnych głów jasna blondynka wzbudza sensację w miejscach publicznych, co pogłębia poczucie wyobcowania wobec trzymających się w grupie Chińczyków. Powoli zaczyna pojmować, że najpopularniejszym chińskim sposobem na rozwiązywanie trudnych problemów jest milczenie i przeczekanie, a reakcją na niezręczną sytuację śmiech. Pawlak jako socjolog z wykształcenia przedstawia różne ciekawe obrazki, chociażby sytuację studentów koreańskich. W Korei Południowej jest moda na studiowanie w Chinach: bo taniej, bo łatwiej się dostać na uniwersytet. Na 6 tys. studentów zagranicznych szanghajskiego Uniwersytetu Jiao Tong 4 tys. to Koreańczycy z Południa. Tworzą oni swoistą subkulturę na uczelni, zaludniają kursy języka chińskiego, ale większość z nich, pozbawiona kurateli surowych rodziców, imprezuje i markuje naukę. Te różne żywe obrazki z życia wielkich miast uzupełniają podróże po Chinach. To majstersztyk opisu. Prawie czujemy, że podróżujemy z autorką - widzimy, jak najpierw toczy bój o bilet, potem o miejsce do stania $\mathrm{w}$ wagonie, w końcu opowiada o towarzystwie robotników migrantów, matek i babć z rozpuszczonymi jak dziadowskie bicze jedynakami, o relacjach z pasażerami i rytuałach podróżnych, takich jak: jedzenie, spanie czy zwykłe siedzenie na podłodze lub na stosie bagaży. Przy tej okazji autorka zastanawia się nad powszechnym w Chinach zjawiskiem plucia i smarkania na podłogę, choć oszczędza czytelnikowi rozważań o mitologicznych czy biologicznych przyczynach tego fenomenu, obcego kulturze europejskiej.

Ciekawe są wizyty w domach, kiedy zupełnie nieznani ludzie okazują wędrowcom gościnność wręcz „staropolską”. Przy okazji można się dowiedzieć, jak w Chinach się mieszka czy też jak się żyje na co dzień w jednym mieszkaniu w rodzinie wielopokoleniowej. Niezwykle interesujące są rozważania na temat hukou, czyli systemu rejestracji ludności, od którego zależy miejsce jednostki w kolektywnym chińskim społeczeństwie. System ten jest w trakcie reformy, gdyż hamuje de facto rozwój gospodarczy poprzez utrudnianie mobilności siły roboczej w dynamicznie rozwijającej się gospodarce. Bez wpisu do hukou jednostka ani jej rodzina nie ma prawa do elementarnej opieki medycznej czy socjalnej, a jej dzieci nie mogą chodzić do szkoły. 
Interesująco autorka opisuje Pekin, Szanghaj i inne wielkie miasta. Potrafi wyeksponować genius loci, w tym warunki podróżowania miejskim transportem, mieszkania czy robienie zakupów. Zachwyca się organizacją opieki medycznej, oczywiście tej płatnej, gdyż powszechna opieka ma jeszcze charakter najbardziej rudymentarny. Poważniejsza choroba oznacza ruinę finansową dla chińskiej rodziny.

Wiele miejsca autorka poświęca rozważaniom o chińskim internecie, z którego korzysta prawie $600 \mathrm{mln}$ internautów, czyli wangmin. Czytelnik dowiaduje się też o sposobach blokowania przez władze dostępu do niektórych zapisów, które zawierają „delikatne kwestie”.

Katarzyna Pawlak odwiedzała mniejszości narodowe o bogatej, choć stopniowo zanikającej kulturze, oraz miejsca, gdzie była wszechobecna zwykła ludzka bieda, przejawiająca się w nędznym odzieniu czy marnym jedzeniu. Udawało się jej zwiedzać klasztory i obserwować ciekawą subkulturę bywalców parków, a także podróżować po rejonach graniczących z Koreą Północną czy Birmą. Poznała też niecodzienną codzienność Mongolii Wewnętrznej. Każdy opis zawiera cenne spostrzeżenia i uwagi. Wprawdzie autorka pominęła podłoże filozoficzne takich zjawisk, jak: konfucjanizm, kult przodków czy komunizm, ale to tylko nadaje książce walor bezpośredniości i autentyzmu.

Bardzo dobra książka, świetnie napisana, umożliwia przybliżenie wspaniałych Chin każdemu. 